\title{
On the Manifestation of the Compulsoriness of Legal Discourse
}

\author{
XIAO Peng \\ School of Foreign Studies, Zhongnan University of Economics and Law, Wuhan, China \\ LI Lan-tu \\ School of Law, Wuhan University, Wuhan, China
}

\begin{abstract}
The French philosopher Michel Foucault believes that discourse is in essence the force exerted on things. In the discourse theory, this kind of power is the vehicle that grants verbal communication structure — "illocutionary force”, which makes the compulsoriness of legal discourse possible and at the same time imposes constraints on it. By introducing the concept of "illocutionary force" from classic discourse theory, the compulsory relationship between the orator and the audience in legal discourse has been revealed.To put it clearly, the relationship consists of external compulsoriness and internal compulsoriness, the former of which can be divided into three categories: "prohibition”, “distinction” and "acknowledgement” and the later encompasses "commentary", “signature” and “paradigm”.
\end{abstract}

Keywords: Legal discourse, illocutionary force

\section{Introduction}

The research on legal language has undergone a turn from static research which focuses on semantics and syntax to dynamic research which centers on pragmatics. From the 1980s to the end of the 20th century, a batch of Chinese scholars (such as Chen Jiong (1998), Wang Jie (1999), Pan Qingyun (1989), Liu Suzhen (1994), Liu Weiming (1996), Jiang Jianyun (1995), Sun Yihua (1997), etc.) took language itself as the research object and analyzed diction features and language styles of written language such as legislative language, legal instruments, lawyers' arguments of defense, etc., by employing traditional methods of description and analysis of philology, which belongs to static and descriptive research at a linguistic level. In recent years, quite a few scholars, represented by Liao Meizhen, began to uphold a "discursive" turn—-that is, they switched their focus from lexical and syntactical features of legal texts to discourse, courtroom discourse dynamics in particular. Based on the transcription of tape-recordings of courtroom trials, the mechanism of question-response interaction of different participants has been systematically examined (Liao, 2003). Besides, some researchers equate "legal discourse” with "legal cogitation” and “legal methodology”. For instance, Li Xudong (2008, p. 87) defines legal discourse as a cognitive framework shared by law professionals, a world of legal meaning which

\footnotetext{
Acknowledgements: This research is supported by “The Fundamental Research Funds for the Central Universities”, Zhongnan University of Economics and Law (Grant Number 2722019JCT018).

XIAO Peng, Ph.D., lecturer, School of Foreign Studies, Zhongnan University of Economics and Law, Wuhan, China. xiaopeng@zuel.edu.cn.

LI Lan-tu, Ph.D., School of Law, Wuhan University, Wuhan, China.
} 
law professionals pay close attention to and the professionalism of law professionals in the modern pluralistic society. Chen Jinzhao (2013, p. 43) contends that legal discourse and legal cogitation are in essence the same and they are the two sides of one thing, which is apparently different from the "legal discourse" illustrated in this article which derives from Saussure's linguistics.

It's believed that the research on legal discourse in China is mainly static textual analysis which revolves around the grammar and vocabulary of legal provisions. Although one aforementioned scholar selected the most contentious courtroom discourse and analyzed courtroom question-response interaction dynamics, there is still a lack of in-depth discussions about the formation and interactive mechanism of legal discourse in common social situations and a further illustration of various power relations in legal discourse and discourse strategies used to achieve power control. It is a more urgent and fundamental task in legal discourse research to reveal the "compulsoriness" in legal cogitation mode that constrains and shapes discourse subjects, illuminate in what way context decides the generation of legal discourse, and analyze how legal discourse is combined with power and institutions and how hidden compulsoriness is exerted.

\section{The Media of the Compulsoriness of Legal Discourse: Illocutionary Force}

The principle of specificity declares that a particular discourse cannot be resolved by a prior system of significations; that we should not imagine that the world presents us with a legible face, leaving us merely to decipher it; it does not work hand in glove with what we already know; there is no pre-discursive fated is posing the word in our favour. We must conceive discourse as a violence that we do to things, or, at all events, as a practice we impose upon them; it is in this practice that the events of discourse find the principle of their regularity. (Foucault, 1971, p. 22)

Illocutionary force is a concept in classic linguistic theory. The British language philosopher J. L. Austin (1962, p. 100) who proposed the notion argued that the "illocutionary force" in the discourse model is parallel to "meaning" in the linguistic model as he remarked, "I want to distinguish force and meaning in the sense in which meaning is equivalent to sense and reference, just as it has become essential to distinguish sense and reference within meaning”. Liu Longgen (2005, p. 120) defines illocutionary force as the speaker's intention mirrored by his/her speech act, namely the specific role played by the discourse in a specific communication scene. Mo Qiyang and Duan Yun (2012, p. 23) believe that the illocutionary force is a power that the orator exerts on the audience through discourse and endeavors to overwhelm his/her inner power in verbal communication. Usually changes in the listener's state (such as thoughts, emotions, and actions) will ensue. The illocutionary force of the speaker overwhelms the listener's innate power tendency and gives rise to changes in his/her state.

It can be concluded from these definitions that the illocutionary force is the power exerted by the orator on the audience to change the latter's will. The addresser is the sender of an action and the addressee the receiver of it. Before the addressee is engaged in communication, he/she always holds personal beliefs. After the addresser exerts an illocutionary force on the addressee through discourse, the latter's state can be altered, and he/she will be guided to act in compliance with the addresser's will if this force is able to overcome the addressee's inherent will. The illocutionary force resembles the compulsoriness of legal discourse in every aspect such as its exertion. Discourse can always limit subjects' choices when they take actions. In every dialogue, there will be a speaker who has an advantage of discourse and gains control of the listener, forcing 
him/her to act or not act no matter if he/she agrees with it or not, otherwise he/she might face legal compulsoriness. In this way, the addresser is capable of dominating and overwhelming the addressee by means of an illocutionary force, during which process the compulsoriness of legal discourse manifests itself.

It should be noted that the addresser and addressee in legal discourse are not visual entities but a function and position. It is not the person who occupies the position that matters but who exerts an illocutionary force of this position. To become the addresser in legal discourse, one must allow legal contexts and educational institutions to compulsorily shape one's own thoughts. One is always subjected to legal contexts: $\mathrm{He} / \mathrm{she}$ could be the addressee as well as the addresser. It is in a meaning network that repeats itself in circles that the addresser and the addressee are converted into, replace and shape each other. Foucault also remarked that he did not believe that there were independent, ubiquitous, and universal subjects and he held a suspicious and even hostile attitude towards that notion. On the opposite, he thought that subjects were shaped by slavery and domination (Bao \& Yan, 1997, p. 19).

Orator/audience is only a symbolic concept constructed by legal discourse and is the subject of legal discourse with dual meanings. The orator is forced to become proactive and responsible thanks to the audience while the audience is subordinate and subject to the acknowledgement of discourse.

Hence everyone is subjected to the constraints of discourse thanks to the compulsoriness imposed by legal discourse. Everyone can become the orator/audience and is at the mercy of legal discourse. "The 'subject' is produced within discourse. This subject of discourse cannot be outside discourse, because it must be subjected to discourse. It must submit to its rules and conventions, to its dispositions of power/knowledge” (Hall, 2009, p. $55)$.

Without the production, accumulation, circulation, and functioning of discourse, these power relations cannot be established or consolidated (Bao \& Yan, 1997, p. 228). The compulsoriness of legal discourse is in essence the fight between the speaker and the listener for power. The power does not refer to unlimited authority such as the traditional right to rule or popular sovereignty in legal discourse, but is "local, continuous, productive, capillary, and exhaustive” (Fraser, 1981, p. 276). In legal discourse, power is never entitative but hidden in the dialogue between the orator and the audience. Whoever obtains the discursive power can dominate the other's thoughts, remarks, and actions. The former legal discourse determines the understanding and deconstruction of the latter discourse and once the latter has been generated, it will give birth to new legal discourse and decides the spread and reproduction of the renewed legal discourse. Legal discourse is not only controlled by power but also generates power. Without the hidden endorsement of power, the communication of legal discourse would not have existed. The majority of people who remain silent in the communication of legal discourse are the subjects suppressed by the discourse because they fail to grasp the expression and paradigm of legal discourse.

\section{The Manifestation of the Compulsoriness of Legal Discourse}

Foucault points out that "while the human subject is placed in relations of production and of signification, he is equally placed in power relations which are very complex" (Dreyfus, Rabinow, \& Foucault, 1983, p. 209). Sara Mills contends that 
in theory, any person could utter anything that they wanted to, but, firstly, people tend to remain, in the choice of their topics of conversation and in the words that they choose, fairly restricted by societal and personal norms, and secondly, people tend to be fairly restricted in terms of the construction of their own desires and needs. So, what we find ourselves wanting to say falls within fairly predictable and restricted sets of parameters. (1997, p. 70)

The compulsoriness of legal discourse can be divided into external compulsoriness and internal compulsoriness based on the logic.

\section{External Compulsoriness}

In Orders of Discourse, Foucault proposed three systems of exclusion that forge discourse: prohibited words, the division of madness, and the will to truth (Foucault, 1971, p. 11). In this paper, the three types of external compulsoriness are respectively referred to as prohibition, distinction, and acknowledgement. They intersect, reinforce, or compensate for each other and form a complex grid which changes continuously and enforces themselves on every speaker and listener with "sweet strength in all its insidious universality" (Foucault, 1971, p. 12).

Prohibition. Prohibition is the most common and familiar expression of compulsoriness. Legal discourse is bound to take place between or among two or more subjects under given circumstances. There will be restrictions on discourse in any society, which is even more obvious when it comes to legal discourse. For instance, legal discourse requires that speakers should conform to laws and regulations and must not spoil the country's image when they deliver speeches; during an august courtroom trial, speakers are requested to articulate coherently and solemnly and forbidden from telling a gag or talking nonsense; only those permitted by law procedures can speak in a courtroom while the spectators can only stay silent; otherwise they will be admonished.

Distinction. Legal discourse prevents prohibited discourse from being generated by means of prohibition. As for events that have entered the scope of legal discourse, the principle of distinction, as a supplementary measure, will dismiss them as heterogeneous discourse and ignore them. Foucault had taken the opposition of reason and madness as an example and discovered that

From the depths of the Middle Ages, a man was mad if his speech could not be said to form part of the common discourse of men. His words were considered null and void, without truth or significance, worthless as evidence, inadmissible in the authentification of acts or contracts, incapable even of bringing about transubstantiation-the transformation of bread into flesh—at Mass. (Foucault, 1971, p. 9)

That is to say, the madman's discourse is disparaged as invalid, which, as a discriminatory distinction, deprives the communicative function of discourse itself. This kind of distinction also abounds in the production of legal discourse. Deeds that can be evaluated and bound by laws are upgraded as legal behaviors while those that cannot be evaluated or bound by laws but exist are compulsorily excluded from legal behaviors. The discursive distinction between legal behavior and illegal behavior has in fact drawn a compulsory boundary for the speaker and listener: They can only talk about those demarcated as legal behaviors. Any other behavior, significant as it might be, will still be avoided in dialogues because they are defined as illegal behaviors.

Acknowledgement. The compulsoriness of acknowledgement is the most obscure in the external system of the compulsoriness of legal discourse. It seems that the pursuit of truth should derive from the free will of discourse subjects rather than outside factors. But it should be noted that "truth" is not a priori but a product of deconstruction, processing, and reproduction. Supported by institutions like schools, academic boards and 
courts, it is employed, assessed, distributed, and redefined on a deeper level. Legal discourses such as "justice" and "fairness" are constructed under the law of commodity economy. However, "instead of official knowledge being the only explanation of things, it was really a case of some explanations winning out over others—often for political reasons. Whichever explanations 'won' became knowledge-and therefore 'truth'” (Danaher, Schirato, \& Webb, 2000, p. 2). In this sense, any recognized concept, axiom, and principle in legal discourse belong to local knowledge and are extracted and constructed under specific dialogues. They are themselves legal discourses and at the same time generate new legal discourses. Considering that these truth-like legal discourses usually rest on institutional support, other legal discourses are forced to seek justification and the potential of being acknowledged by institutions from these well-constructed discourses when they attempt to generate new discourses, spread themselves, and exert authority. No legal professional would announce that "I do not pursue justice" and even if such a person exists, his/her discourse will immediately be discriminatorily demarcated as "nonsense". In summary, speakers and listeners are seemingly using legal discourses such as "justice" and "fairness" freely, but the moment discourses are spoken and written, well-constructed truths suddenly appear and control every speaker's thoughts without being noticed, and the moment speakers finish speaking and writing, they quietly deconstruct themselves and disappear in the dark. Legal discourse is supported materially by speeches and writings, nevertheless, it is not an entity but a function that suddenly constructs and deconstructs itself in a specific moment and then vanishes.

\section{Internal Compulsoriness}

Foucault also enunciated the internal procedures of the compulsoriness of discourse, which are grouped into three types: commentary, rarefaction, and disciplines (Foucault, 1971, pp. 12-15). Accordingly, there are similar procedures that control and delimit discourse in the field of law, which are summarized as commentary, signature, and paradigm in this article. If the external compulsoriness of legal discourse dominates listeners, then the internal compulsoriness of legal discourse can be deemed as a self-filter system within the discourse which rejects those that do not comply with the rules of the compulsoriness of legal discourse.

Commentary. "There is barely a society without its major narratives, told, retold and varied; formulae, texts, ritualized texts to be spoken in well-defined circumstances” (Foucault, 1971, p. 12). No matter it is in the west or the east, it's acknowledged that texts are abundant in connotations, which should be probed into. For example, the glossators, a legal school which centered on the Roman law in the 14th century in west Europe, is still relevant today. The predecessors' texts are constantly commented and interpreted by later generations and passed on from generation to generation. However, later generations would always annotate their predecessors' texts by interpreting them from mainstream perspectives of their times, which are tantamount to truths at the time. This might finally render annotated texts totally different from their originals. In the production of legal discourse, this phenomenon abounds. Based on the same legal texts, different interpretations of policies and political guidance always generate discourses that deviate greatly from the original ones. But texts only exist silently and objectively. It is the commentaries given by later generations rather than speakers who composed the initial texts that multiply discourses. On the other hand, no matter how varied the commentaries are, they are still mere interpretations that enrich legal texts and cannot depart from texts as much as literary discourses. They can bring about changes in texts on the ground of removing the ambiguity of texts and enriching texts but 
can never go beyond the applicable fields of the texts. For example, the clauses of criminal law are flooded with legal discourses such as "serious offenses" and "very serious offenses", but exactly what offense can be classified as these two? Of course, these criteria change with time. As time goes by, judicial interpretations continuously inject new discourse into the clauses and in turn the new discourses are producing even newer discourses for the society based on the support of judicial institutions, and compulsorily categorize a variety of criminal offenses as legal discourse. Nonetheless, no listener can group behaviors to which criminal laws do not apply while private laws apply into discourses of criminal laws because whatever the commentaries are like, they are always interpretations and elaborations of the clauses of criminal law. In this sense, no matter how free a commentary seems to be, it is subject to control in essence.

Signature. In daily discourse, signatures are not necessary. For example, there are no addressers or addressees in texts such as package inserts, conference guidelines, and technical materials. We only need to grasp their "meanings" and it does not matter who the addressers are. But signatures are commonplace in legal discourse. One classic example is court order. Every court verdict is printed with "the People's Court" as its signature and every social member, whether he/she is a courtroom participant or not, must conform to the ruling. There is double compulsoriness: not only because that a court ruling is guaranteed by compulsoriness but also that the legal expression of "the People's Court" itself conveys the coercion exerted by the speaker on the listener. The American scholar Damaska (1986, p. 19) argues that "because the institution must be univocal so as not to be equivocal, the announcement of a judgement made by several officials nullifies prior internal dissent: those who disagree must now repress their feelings”. Generally, the collegiate bench must deliberate a case before a court order is delivered. In the process of deliberation, chief judges do not always obtain final support. No matter how great the differences within the adjudication division are, once a ruling is made, the joint signature will be "the People's Court", which gains double statuses of a speaker and a listener: As a listener, even if the chief judge who drafts the court order does not agree with the collegiate bench, he/she must submit to the restraints of litigant discourse, otherwise the signature of "the People's Court" cannot be written on the verdict; as a speaker, the signature represents a country's public power and is assumed by the public as an embodiment of fairness, rule of law and justice — unless it is overturned by the signature of a higher court. This kind of double compulsoriness is upgraded to the concept of "res judicata" by way of legal discourse and reinforced by academic, educational, and judicial institutions to finally establish as a legal doctrine: "judicial credibility". Here signatures are "lying at the origins of their significance, as the seat of their coherence" (Foucault, 1971, p. 14).

Paradigm. Every discipline is bound to have specific norms, technical requirements, and research methodologies, and the discipline of law is a typical example. Having undergone a long time of development, the professionalism of law always impresses people. Within the discipline of law and even just department law, every division is distinct from each other and their great differences almost get people suspect whether they share the same paradigm of the discipline of law. In particular, those who are involved in legal practices and those in legal theories only respectively adhere to their own discourse systems and ways of thinking. It seems that speakers of legal discourse are speaking on their own, but their discourses are greatly influenced by the compulsoriness of legal discourse network. The discipline of law has posited paradigm, style, expression, and orientation for them, to which if they do not succumb, they will be rejected by the system of law. 
People have often wondered how on earth 19th-century botanists and biologists managed not to see the truth of Mendel's statements. But it was precisely because Mendel spoke of objects, employed methods and placed himself within a theoretical perspective totally alien to the biology of his time. (Foucault, 1971, p. 16)

It's the same with present law professionals. For instance, it is Chen Jinzhao's (2013, p. 46) contention that legal discourse takes law as a specialized rhetoric, legal words as key words in people's mind, and rule of law as the major factor that influences people's decision-making. He advocates that "the power rhetoric" should translate into to "the legal discourse", which concerns whether the construction of China's rule of law will succeed or not. Here the speaker is a "discipline”, which decides that the listener's discourse will highlight the particularity of law as a specialized discipline, emphasizes discursive components such as "rule of law" and "legal phrases", and urges that "the power rhetoric" should be removed from the legal discourse.

\section{Conclusion: The "Illusion” About Legal Discourse}

As Foucault first proposed "the compulsoriness of discourse", this article can be deemed as the epitome of his thought in the field of legal discourse. By clarifying the logic of legal discourse, it's discovered that the compulsoriness of legal discourse is also composed of internal compulsoriness and external compulsoriness, which doubtless is not a coincidence. In fact, in modern countries, the legal system serves as the "integrator of social order": It is not only a set of behavioral norms but also the criterion for legitimacy judgement, which coincides exactly with what Foucault expounds in Orders of Discourse. From this angle, the compulsoriness of discourse and the compulsoriness of discourse are demonstrated differently, but they possess the same meanings and functions in various scenarios and contexts.

More importantly, the examination of the reproduction of the legal discourse in this paper helps us to identify "subjective interpretations" in the history of legal thought more clearly. The traditional history of legal thought revolves around how jurists came up with their representative ideas and how these ideas became widespread till they influenced and even decided the revolution and renewal of law. But one should note that this narrative was the opinion of authors who wrote about the history of legal thought. At that time, jurists did not know what influence their ideas would have on the later generations. We'd rather say that the contributions made by the jurists' ideas to the development of the discipline of law are what later authors expected than objective. The history of legal thought can be likened to a "novel" in some sense, whose "happy ending" is skillfully edited and elaborated by later generations. In this story, every jurist's contribution is clear and definite, one step higher than their predecessors', and points to the "continuous progress" of law. But this continuity is just a falsehood and it originates in a long-standing but false assumption: Human history is well-designed and driven by plans and law. In this type of legal discourse theory, the continuity, tendency, and coherence in meaning of the history of legal thought is very likely the outcome of processed discontinuous historical events by later generations.

Therefore, law professionals should not be obsessed with the quest for the law of the development of the history of legal thought any more, but to treat discourses that reflect thoughts, remarks, and behaviors of subjects of legal discourse as historical remains instead of attempting to compulsorily integrate them into a grand legal theory. 


\section{References}

Austin, J. L. (1962). How to do things with words. Oxford: Clarendon Press.

Bao, Y. M., \& Yan, F. (1997). 权力的眼睛: 福柯访谈录 [Michel Foucault]. Shanghai: Shanghai People’s Publishing House. Chen, J. (1998). 法律语言学概论 [An introduction to legal linguistics]. Xi’an: Shaanxi People’s Publishing House.

Chen, J. Z. (2013). 权力修辞向法律话语的转变一展开法治思维与实施法治方式的前提 [The changes from the power rhetoric to the legal discourse]. Science of Law (Journal of Northwest University of Political Science and Law), 31(5), 43-53.

Damaska, M. R. (1986). The faces of justice and state authority: A comparative approach to the legal process. New Haven: Yale University Press.

Danaher, G., Schirato, T., \& Webb, J. (2000). Understanding Foucault. St. Leonards, N.S.W.: Allen \& Unwin.

Dreyfus, H. L., Rabinow, P., \& Foucault, M. (1983). Michel Foucault: Beyond structuralism and hermeneutics. Chicago: University of Chicago Press.

Foucault, M. (1971). Orders of discourse. Social Science Information, 10(2), 7-30.

Fraser, N. (1981). Foucault on modern power: Empirical insights and normative confusions. PRAXIS International, 3, $272-287$.

Hall, S. (2009). Representation: Cultural representations and signifying practices. London: Sage.

Jiang, J. Y. (1995). 法律语言与言语研究 [Research on legal language and discourse]. Beijing: Qunzhong Publishing House.

Li, X. D. (2008). 法律话语的概念及其意义 [The concept and significance of legal discourse]. In H. Y. Ge (Ed.), Legal methodology and legal cogitation (pp. 86-96). Beijing: Law Press China.

Liao, M. Z. (2003). 法庭问答及其互动研究 [Research on courtroom question-response interaction]. Beijing: Law Press China.

Liu, L. G. (2005). 语力概念与意义表征 [The concept of illocutionary force and the exposition of meaning]. Journal of Northeast Normal University (Philosophy and Social Sciences), 3, 120-124.

Liu, S. Z. (1994). 法律的语言本体 [The essence of law is language]. Journal of Yanan University (Social Science Edition), 4, 86-90.

Liu, W. M. (1996). 法律英语的词源与专门术语 [The etymology and terminology of legal English]. Journal of Northwest Normal University (Social Sciences), 4, 89-91.

Mills, S. (1997). Discourse. London: Routledge.

Mo, Q. Y., \& Duan, Y. (2012). 言语行为语力的认知语言学研究 [Research on the illocutionary force of speech acts from the perspective of cognitive linguistics]. Foreign Languages Research, 3, 21-26.

Pan, Q. Y. (1989). 法律语言艺术 [The art of legal language]. Shanghai: Xuelin Publishing House.

Sun, Y. H. (1997). 法律语言学 [Legal linguistics]. Changsha: Hunan People’s Publishing House.

Wang, J. (1999). 法律语言研究 [Research on legal language]. Guangzhou: Guangdong Education Publishing House. 